\title{
Glycerol Derivatives and Sterols from Sargassum parvivesiculosum
}

\author{
Shu-Hua QI, ${ }^{*, a}$ Si Zhang, ${ }^{a, b}$ Jian-She HuAng, ${ }^{a}$ Zhi-Hui XIAO, ${ }^{a}$ Jun Wu, ${ }^{a}$ and Li-Juan LonG ${ }^{a}$ \\ ${ }^{a}$ Guangdong Key Laboratory of Marine Materia Medica, South China Sea Institute of Oceanology, The Chinese Academy \\ of Sciences; and ${ }^{b}$ Hainan Key lab of Tropical Marine Biology and Technology, South China Sea Institute of Oceanology, \\ The Chinese Academy of Sciences; 164 West Xingang Road, Guangzhou 510301 Guangdong, People's Republic of China. \\ Received February 16, 2004; accepted April 23, 2004
}

\begin{abstract}
Five glycerol derivatives $(1-5)$ and three sterols $(6-8)$ were isolated from the EtOH extraction of the brown alga of Sargassum parvivesiculosum. On the basis of spectroscopic methods, their structures were elucidated as 1,3-di- $O$-[2',2'-di-( $p$-phenylene) isopropylidene] glycerol (1), (2S)-1- $O$-heptatriacontanoyl glycerol (2), $(2 S)$-1,2-di$O$-palmitoyl-3- $O$-(6-sulpho- $\alpha$-D-quinovopyranosyl) glycerol (3), (2S)-1- $O$-palmitoyl glycerol (4), (2S)-1,3-di-( $O$ palmitoyl)-2- $O$-octadecanoyl glycerol (5), 24-ethylcholest-5,23Z-dien-3 $\beta, 28 \zeta$-diol (6), 24-vinylcholest-5-en-24 $\zeta$-hydroperoxy (7), 24-ethylcholest-4,24(28)-dien-3 $\beta$-ol (8), respectively. Among them, 1 and 2 were new.
\end{abstract}

Key words Sargassum parvivesiculosum; glycerol derivative; sterol

Sargassum parvivesiculosum is a common brown alga, widely distributed in southeast China. It is used for treating tracheitis and thyroiditis in folk medicine, and also has the activity of inhibiting tumor. ${ }^{1)}$ The same genus of $S$. angustifolium (Turn.) C. Ag. and S. fusiforme (Harv.) Setch, both known as a "marine alga", have been collected in the Chinese pharmacopeia. The EtOH extraction of $S$. carpophyllum J. AG. can clearly induce the morphological abnormality of Pyricularia oryzae. ${ }^{2)}$ Glycerides and sterols are rich in this genus. $^{2-5)}$ Some of them have activity against Pyricularia oryzae. ${ }^{5)}$ During the course of searching the chemical constituents of S. parvivesiculosum, five glycerol derivatives and three sterols were obtained. On the basis of spectroscopic methods, their structures were elucidated as $1,3-\mathrm{di}-O-\left[2^{\prime}, 2^{\prime}-\right.$ di-( $p$-phenylene) isopropylidene] glycerol (1), (2S)-1-O-heptatriacontanoyl glycerol (2), (2S)-1,2-di-O-palmitoyl-3-O-(6sulpho- $\alpha$-D-quinovopyranosyl) glycerol (3) $\left.{ }^{6}\right) \quad(2 S)-1-O$ palmitoyl glycerol (4), ${ }^{5)}$ (2S)-1,3-di-( $O$-palmitoyl)-2-O-octadecanoyl glycerol (5), ${ }^{5}$ 24-ethylcholest-5,23Z-dien$3 \beta, 28 \zeta$-diol (6), ${ }^{7)} \quad 24$-vinylcholest-5-en-24 $\zeta$-hydroperoxy (7), ${ }^{2)}$ 24-ethylcholest-4,24(28)-dien-3 $\beta$-ol $(\mathbf{8}),{ }^{4)}$ respectively. Among them, $\mathbf{1}$ and $\mathbf{2}$ were new. Furthermore, according to the literature, $\mathbf{3}$ exhibited activity against Pyricularia oryzae, cytotoxicity against P388 and HL-60 tumor cells, and weak cytotoxicity against MCF-7 and A549 human tumor cells ${ }^{8)}$; and $\mathbf{6}$ showed cytotoxic activity against HL-60 tumor cells $\left(\mathrm{IC}_{50}=7.8 \mu \mathrm{g} / \mathrm{ml}\right)^{7}{ }^{7}$

\section{Results and Discussion}

Compound 1 was obtained as white powder, showing the molecular formula of $\mathrm{C}_{18} \mathrm{H}_{20} \mathrm{O}_{3}$ as determined by EI-MS and NMR spectra. Its IR spectrum showed absorption bands for $-\mathrm{OH}\left(3433 \mathrm{~cm}^{-1}\right)$ and aromatic ring $\left(1562,1510 \mathrm{~cm}^{-1}\right)$, while the UV spectrum exhibited maximum absorption at
206, 228, 255, 276 and $280 \mathrm{~nm}$ (aromatic ring). With the assistance of 2D-NMR studies, including ${ }^{1} \mathrm{H}-{ }^{1} \mathrm{H}$ COSY, HMQC and HMBC experiments, all of the assignments of ${ }^{13} \mathrm{C}$ - and ${ }^{1} \mathrm{H}-\mathrm{NMR}$ data of $\mathbf{1}$ were determined. The signals at $\delta_{\mathrm{C}} 157.4$ (s, C-1a, 1b), 143.6 (s, C-4a, 4b), 127.9 (d, C-3a, 5a, 3b, 5b), 114.8 (d, C-2a, 6a, 2b, 6b), and corresponding $\delta_{\mathrm{H}} 7.09(4 \mathrm{H}, \mathrm{d}, J=8.0 \mathrm{~Hz}, \mathrm{H}-3 \mathrm{a}, 5 \mathrm{a}, 3 \mathrm{~b}, 5 \mathrm{~b}), 6.90(4 \mathrm{H}, \mathrm{d}$, $J=8.0 \mathrm{~Hz}, \mathrm{H}-2 \mathrm{a}, 6 \mathrm{a}, 2 \mathrm{~b}, 6 \mathrm{~b})$ in the ${ }^{13} \mathrm{C}-$ and ${ }^{1} \mathrm{H}-\mathrm{NMR}$ spectra of 1 , indicated the existence of the same two $p$-substituted phenylenes, which was further supported by the HMBC spectrum showing correlations of $\mathrm{H}-3 \mathrm{a}, 5 \mathrm{a} / 3 \mathrm{~b}, 5 \mathrm{~b}, \mathrm{H}-2 \mathrm{a}$, $6 \mathrm{a} / 2 \mathrm{~b}, 6 \mathrm{~b}$ with $\mathrm{C}-1 \mathrm{a} / 1 \mathrm{~b}, \mathrm{C}-4 \mathrm{a} / 4 \mathrm{~b}$, and ${ }^{1} \mathrm{H}-{ }^{1} \mathrm{H}$ COSY spectrum showing correlations of $H-3 a / 5 a / 3 b / 5 b$ with $H-2 a / 6 a / 2 b / 6 b$, respectively (Fig. 2).

The ${ }^{13} \mathrm{C}$ - and ${ }^{1} \mathrm{H}$-NMR spectra of $\mathbf{1}$ also showed typical signals for a fully substituted glycerol moiety $\left[\delta_{\mathrm{C}} 69.9(\mathrm{t}, \mathrm{C}\right.$ $1,3), 68.7(\mathrm{~d}, \mathrm{C}-2), \delta_{\mathrm{H}} 4.48(4 \mathrm{H}, \mathrm{m}, \mathrm{H}-1,3), 4.64(1 \mathrm{H}, \mathrm{m}, \mathrm{H}-$ 2)], ${ }^{9,10)}$ which was identified by the correlations of $\mathrm{H}-1,3$ with $\mathrm{C}-2$, and $\mathrm{H}-2$ with $\mathrm{C}-1,3$ in the HMBC spectrum (Fig. 2). The HMBC correlations of $\mathrm{H}-1 / 3$ with $\mathrm{C}-1 \mathrm{a} / 1 \mathrm{~b}$, respectively, suggested that the same two $p$-substituted phenylenes were symmetrically attached to $\mathrm{C}-1$ and $\mathrm{C}-3$ by ether bond, respectively. Furthermore, in the HMBC spectrum, correlations of H-3a, $5 \mathrm{a}, 3 \mathrm{~b}, 5 \mathrm{~b}, \mathrm{H}-1^{\prime}, 3^{\prime}\left(\delta_{\mathrm{H}} 1.58,6 \mathrm{H}, \mathrm{s}\right)$ with $\mathrm{C}-2^{\prime}$ $\left(\delta_{\mathrm{C}} 41.5, \mathrm{~s}\right)$, and $\mathrm{H}-1^{\prime}, 3^{\prime}$ with $\mathrm{C}-4 \mathrm{a}, 4 \mathrm{~b}$, respectively, suggested the same two $p$-substituted phenylenes also simultaneously attached to an isopropylidene. Based on the above evidence, the structure of 1 was elucidated to be 1,3-di-O-[2',2'di-(p-phenylene) isopropylidene] glycerol (Fig. 1).

Compound 2 was obtained as white powder. It showed in its negative-ion FAB-MS spectrum a quasimolecular ion peak at $m / z 483[\mathrm{M}-1]^{-}$in accordance with the formula of $\mathrm{C}_{30} \mathrm{H}_{60} \mathrm{O}_{4}$ as determined by HR-FAB-MS, and confirmed
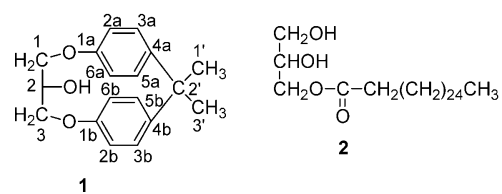

Fig. 1. Structures of Compounds $\mathbf{1}-\mathbf{3}$

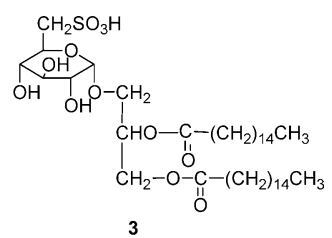

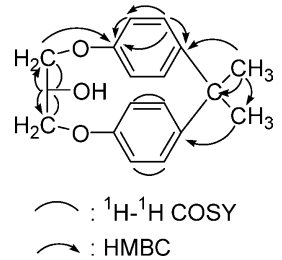

Fig. 2. Key ${ }^{1} \mathrm{H}-{ }^{1} \mathrm{H}$ COSY and HMBC Correlations of Compound $\mathbf{1}$ 
from the ${ }^{13} \mathrm{C}$ - and DEPT NMR spectra. Its IR spectrum revealed absorption bands for $-\mathrm{OH}$ at $3419 \mathrm{~cm}^{-1}$ and $\mathrm{C}=\mathrm{O}$ at $1733 \mathrm{~cm}^{-1}$. The ${ }^{13} \mathrm{C}$ - (DEPT) and ${ }^{1} \mathrm{H}-\mathrm{NMR}$ spectra of 2 showed signals for a fatty acid moiety $\left[\delta_{\mathrm{C}} 14.0(\mathrm{q}), 22.6(\mathrm{t})\right.$, $24.8(\mathrm{t}), 29.0-29.6(\mathrm{t}), 31.8(\mathrm{t}), 34.1(\mathrm{t}), 174.3(\mathrm{~s}), \delta_{\mathrm{H}} 0.85$ $(3 \mathrm{H}, \mathrm{t}, J=6.4 \mathrm{~Hz}), 1.22\left(\mathrm{br} \mathrm{s}, n \times \mathrm{CH}_{2}\right), 1.60(2 \mathrm{H}, \mathrm{m}), 2.33$ $(2 \mathrm{H}, \mathrm{t}, J=7.5 \mathrm{~Hz})]$, two oxymethylene $\left[\delta_{\mathrm{C}} 63.2,65.1, \delta_{\mathrm{H}}\right.$ $4.17(2 \mathrm{H}, \mathrm{m}), 3.67(1 \mathrm{H}, \mathrm{dd}, J=11.6,3.8 \mathrm{~Hz}), 3.55(1 \mathrm{H}$, dd, $J=11.6,5.8 \mathrm{~Hz})]$, and one oxymethine $\left[\delta_{\mathrm{C}} 70.2, \delta_{\mathrm{H}} 3.92(1 \mathrm{H}\right.$, $\mathrm{m})$ ]. These data suggested that 2 was a fatty acid-1glyceride ${ }^{9,10)}$; this was supported by the HMBC spectrum. In the HMBC spectrum, correlations of $\mathrm{H}-1\left(\delta_{\mathrm{H}} 4.17,2 \mathrm{H}, \mathrm{m}\right)$, H-3a $\left(\delta_{\mathrm{H}} 3.55,1 \mathrm{H}, \mathrm{dd}, J=11.6,5.8 \mathrm{~Hz}\right)$ with $\mathrm{C}-2\left(\delta_{\mathrm{C}} 70.2\right.$, $\mathrm{d})$, and H-1, H-2 $\left(\delta_{\mathrm{H}} 3.92,1 \mathrm{H}, \mathrm{m}\right)$ with $\mathrm{C}-3\left(\delta_{\mathrm{C}} 63.2, \mathrm{t}\right)$ indicated the presence of an unsymmetrical substitution glycerol moiety, furthermore, correlations of $\mathrm{H}-1, \mathrm{H}-2^{\prime}\left(\delta_{\mathrm{H}} 2.33,2 \mathrm{H}\right.$, t, $J=7.5 \mathrm{~Hz}), \mathrm{H}-3^{\prime}\left(\delta_{\mathrm{H}} 1.60,2 \mathrm{H}, \mathrm{m}\right)$ with C-1' $\left(\delta_{\mathrm{C}} 174.3, \mathrm{~s}\right)$ indicated the acyl of fatty acid moiety attached to $\mathrm{C}-1$. According to the FAB-MS spectrum showing the molecular weight, the fatty acid moiety should be heptacosanoic acid. Based on the literature which reported that the analogue right optical rotation glyceride had an absolute configuration of $2 S,{ }^{11)}$ the structure of $\mathbf{2}$ was elucidated as (2S)-1-O-heptatriacontanoyl glycerol $\left\{[\alpha]_{\mathrm{D}}^{26.2}+7.5^{\circ}(c=0.20\right.$, pyridine $\left.)\right\}$ (Fig. 1).

3 showed a quasimolecular ion peak at $m / z 793[\mathrm{M}-1]^{-}$in its negative-ion ESI-MS spectrum. Together with ${ }^{1} \mathrm{H}$ - and ${ }^{13} \mathrm{C}$-NMR spectral data, a molecular formula $\mathrm{C}_{41} \mathrm{H}_{78} \mathrm{O}_{12} \mathrm{~S}$ was established. Its IR spectrum indicated the presence of a sulphonyl group $\left(1121,1028,792 \mathrm{~cm}^{-1}\right)$. The ${ }^{1} \mathrm{H}-$ and ${ }^{13} \mathrm{C}-$ NMR spectra closely resembled those of $(2 S)$-1,2-di- $O$-miristoyl-3-O-(6-sulpho- $\alpha$-D-quinovopyranosyl) glycerol and other analogous compounds. ${ }^{6}$ Treatment of $\mathbf{3}$ with sodium methoxide-methanol gave 6-sulpho-quinovopyranosyl glycerol (3a) (identified by ${ }^{1} \mathrm{H}-,{ }^{13} \mathrm{C}-\mathrm{NMR}$ spectra and by comparison with literature data $^{12)}$ ) and methyl palmitate (analysed by GC mass spectrometry). Based on these findings, 3 was determined to be (2S)-1,2-di- $O$-palmitoyl-3-O(6-sulpho- $\alpha$-D-quinovopyranosyl) glycerol which had even been isolated from the brown alga of Ishige okamurai. The element of sulphur was rich in the brown alga, but this was the first report of $\mathbf{3}$ obtained from the genus of Sargassum.

\section{Experimental}

General Experimental Procedures All the mps were obtained on an XRC-1 micromelting apparatus and were uncorrected. Optical rotations were measured with a Horiba SEAP-300 spectropolarimeter. UV spectra were measured with a Shimadzu double-beam 210A spectrophotometer in $\mathrm{MeOH}$ solution. IR ( $\mathrm{KBr}$ ) spectra were obtained on a Bio-Rad FTS-135 infrared spectrophotometer. ${ }^{1} \mathrm{H}-,{ }^{13} \mathrm{C}-\mathrm{NMR}$ and $2 \mathrm{DNMR}$ spectra were recorded on a Bruker DRX-500 MHz NMR spectrometer with TMS as internal standard. EI-MS and FAB-MS spectral data were obtained on a VG Autospec-3000 spectrometer, and $70 \mathrm{eV}$ for EI-MS. ESI-MS spectral data were obtained on a $\mathrm{LCQ}^{\mathrm{DECA}}$ XP HPLC/MS ${ }^{\mathrm{n}}$ spectrometer. Silica gel (200300 mesh) for column chromatography and $\mathrm{GF}_{254}$ for TLC were obtained from Qindao Haiyang Chemical Co., Ltd, Qindao, China.

Plant Material The brown alga of Sargassum parvivesiculosum was collected from Sanya, Hainan province, China, in May 2002. It was identified by Prof. S. Zhang, South China Sea Institute of Oceanology, Academia Sinica. The voucher specimen (No. 2002-5) was deposited in the herbarium of the Department of Taxonomy, South China Sea Institute of Oceanology, Academia Sinica, Guangzhou, China.

Extraction and Isolation The air-dried and powdered bodies $(18.0 \mathrm{~kg})$ of $S$. parvivesiculosum were extracted with EtOH three times under reflux, and the solvent was evaporated in vacuo. The residue was partitioned in $\mathrm{H}_{2} \mathrm{O}$ and extracted with EtOAc and $n$ - $\mathrm{BuOH}$ three times, respectively. The EtOAc and $n-\mathrm{BuOH}$ extracts were concentrated in vacuo to afford $130 \mathrm{~g}$ and $53 \mathrm{~g}$ of residue, respectively. The EtOAc portion was subjected to column chromatography $(\mathrm{CC})$ on silica gel, using petroleum ether-EtOAc gradients (from 1:0 to EtOAc) as eluents. Combining the fractions with TLC $\left(\mathrm{GF}_{254}\right)$ monitoring, eight fractions were obtained. Fraction $1(10 \mathrm{~g})$ was then subjected to CC on silica gel, eluted with petroleum ether-EtOAc gradient to give $5(18 \mathrm{mg})$. Fraction $2(23 \mathrm{~g})$ was subjected to $\mathrm{CC}$ on silica gel, eluted with $\mathrm{CHCl}_{3}-$ EtOAc $(10: 1$ to $10: 3)$ to give $\mathbf{1}(8 \mathrm{mg})$. Fraction $\mathbf{3}(7 \mathrm{~g})$ was subjected to $\mathrm{CC}$ on silica gel, eluted with $\mathrm{CHCl}_{3}$-EtOAc gradients (from $5: 1$ to $4: 1)$ to give $2(10 \mathrm{mg}), 4(9 \mathrm{mg}), 6(11 \mathrm{mg})$. Fraction $5(23 \mathrm{~g})$ was subjected to $\mathrm{CC}$ on silica gel, eluted with $\mathrm{CHCl}_{3}-\mathrm{Me}_{2} \mathrm{CO}$ (from $10: 1$ to $10: 3)$ to give $7(8 \mathrm{mg})$ and $\mathbf{8}(9 \mathrm{mg})$. The $n-\mathrm{BuOH}$ portion was subjected to column chromatography $(\mathrm{CC})$ on silica gel, eluted with $\mathrm{CHCl}_{3}-\mathrm{MeOH}$ gradients (from 1:0 to $\mathrm{MeOH}$ ) to give 3 (26 mg).

Alkaline Hydrolysis and GC Analysis Compound $3(5.0 \mathrm{mg})$ in dry $\mathrm{MeOH}(1 \mathrm{ml})$ was separately treated with $5 \% \mathrm{NaOMe}-\mathrm{MeOH}(0.5 \mathrm{ml})$ at room temperature for $10 \mathrm{~min}$. The reaction mixture was neutralized with Dowex $50 \mathrm{~W} \times 8$ and the resin removed by filtration. The filtrate was extracted with hexane and the hexane layer was concentrated to yield fatty acid methyl esters. This was analysed by GC-MS: Hewlett-Packard 5890 GC equipped with a mass-selective detector MSD $5970 \mathrm{MS}$, a split injector and a fused-silica column HP-5 $(25 \mathrm{~m} \times 0.2 \mathrm{~mm}$; i.d. $0.33 \mathrm{~mm}$ film); column temp. $230{ }^{\circ} \mathrm{C}$, carrier $\mathrm{N}_{2}$, flow rate $30 \mathrm{ml} / \mathrm{min}$. $t_{\mathrm{R}}$ (min) of methyl palmitate was 12.5 , which was identical to the authentic standard methyl palmitate. Removal of the solvent from the $\mathrm{MeOH}$ layer under reduced pressure gave a residue which was purified by silica gel $\mathrm{CC}\left(\mathrm{CHCl}_{3}-\mathrm{MeOH}-\mathrm{H}_{2} \mathrm{O}, 6: 4: 1\right)$ to furnish $\mathbf{3 a}$.

1,3-Di-O-[2',2'-di-(p-phenylene) Isopropylidene] Glycerol (1): White powder. $\mathrm{C}_{18} \mathrm{H}_{20} \mathrm{O}_{3} \cdot{ }^{1} \mathrm{H}-\mathrm{NMR}\left(500 \mathrm{MHz}\right.$, pyridine- $\left.d_{5}\right) \delta_{\mathrm{H}}: 7.09(4 \mathrm{H}, \mathrm{d}, J=8.0$ Hz, H-3a, 5a, 3b, 5b), 6.90 (4H, d, $J=8.0 \mathrm{~Hz}, \mathrm{H}-2 \mathrm{a}, 6 \mathrm{a}, 2 \mathrm{~b}, 6 \mathrm{~b}), 1.58(6 \mathrm{H}, \mathrm{s}$, $\left.\mathrm{H}-1^{\prime}, 3^{\prime}\right), 4.48$ (4H, m, H-1 and $\left.\mathrm{H}-3\right), 4.64$ (1H, m, H-2). ${ }^{13} \mathrm{C}-\mathrm{NMR}$ $\left(125 \mathrm{MHz}\right.$, pyridine- $\left.d_{5}\right) \delta_{\mathrm{C}}: 157.4(\mathrm{~s}, \mathrm{C}-1 \mathrm{a}, 1 \mathrm{~b}), 143.6(\mathrm{~s}, \mathrm{C}-4 \mathrm{a}, 4 \mathrm{~b}), 127.9$ (d, C-3a, 5a, 3b, 5b), 114.8 (d, C-2a, 5a, 2b, 5b), 30.4 (q, C-1', 3'), 41.5 (s, C$\left.2^{\prime}\right), 69.9$ (t, C-1, 3), 68.7 (d, C-2). IR (KBr) cm $\mathrm{cm}^{-1}: 3435,3000,2923,2850$, $1730,1630,1510,1104,826,802$. UV $\lambda_{\max }(\mathrm{MeOH}) \mathrm{nm}: 209,229,256,277$, 284. EI-MS $m / z: 284[\mathrm{M}]^{+}(10), 269$ [M-15] (30), 256 (13), 228 (8), 213 (25), 191 (8), 168 (5), 139 (20), 119 (16), 99 (20), 85 (18), 71 (30), 60 (100), 43 (85). HR-EI-MS $m / z$ : $284.1408[\mathrm{M}-\mathrm{H}]^{-}$(Calcd for $\mathrm{C}_{18} \mathrm{H}_{20} \mathrm{O}_{3}$ : 284.1412).

(2S)-1-O-Heptatriacontanoyl Glycerol (2): White powder. mp $64-65^{\circ} \mathrm{C}$. $\mathrm{C}_{30} \mathrm{H}_{60} \mathrm{O}_{4} \cdot{ }^{1} \mathrm{H}-\mathrm{NMR}\left(500 \mathrm{MHz}, \mathrm{CDCl}_{3}\right) \delta_{\mathrm{H}}: 0.85\left(3 \mathrm{H}, \mathrm{t}, J=6.4 \mathrm{~Hz}, \mathrm{Me}-27^{\prime}\right)$, $1.22\left(46 \mathrm{H}\right.$, brs, H-4' to H-26') $1.60\left(2 \mathrm{H}, \mathrm{m}, \mathrm{H}-3^{\prime}\right), 2.33(2 \mathrm{H}, \mathrm{t}, J=7.5 \mathrm{~Hz}$, H-2' $), 3.55$ (1H, dd, $J=11.6,5.8 \mathrm{~Hz}, \mathrm{H}-3 \mathrm{a}), 3.67(1 \mathrm{H}, \mathrm{dd}, \mathrm{J}=11.6,3.8 \mathrm{~Hz}$, $\mathrm{H}-3 \mathrm{~b}), 3.92$ (1H, m, H-2), 4.17 (2H, m, H-1). ${ }^{13} \mathrm{C}-\mathrm{NMR}\left(125 \mathrm{MHz}, \mathrm{CDCl}_{3}\right)$ $\delta_{\mathrm{C}}: 65.1(\mathrm{C}-1), 70.2(\mathrm{~d}, \mathrm{C}-2), 63.3(\mathrm{t}, \mathrm{C}-3), 174.4\left(\mathrm{~s}, \mathrm{C}-1^{\prime}\right), 34.1\left(\mathrm{t}, \mathrm{C}-2^{\prime}\right)$, $24.8\left(\mathrm{t}, \mathrm{C}-3^{\prime}\right), 29.0-29.6\left(\mathrm{t}, \mathrm{C}-4^{\prime}\right.$ to $\left.\mathrm{C}-24^{\prime}\right), 31.8\left(\mathrm{t}, \mathrm{C}-26^{\prime}\right), 22.6\left(\mathrm{t}, \mathrm{C}-25^{\prime}\right)$, 14.0 (q, C-27'). IR (KBr) cm ${ }^{-1}: 3419,2920,2850,1733,1469,1389,1180$, 992. Negative FAB-MS m/z: $483[\mathrm{M}-1]^{-}(70), 376$ (13), 255 (100). HR FAB-MS $m / z: 483.4443[\mathrm{M}-\mathrm{H}]^{-}$(Calcd for $\mathrm{C}_{30} \mathrm{H}_{59} \mathrm{O}_{4}: 483.4413$ ). $[\alpha]_{\mathrm{D}}^{26.2}+7.5^{\circ}(c=0.20$, pyridine $)$.

$(2 S)$-1,2-Di- $O$-palmitoyl-3- $O$-(6-sulpho- $\alpha$-D-quinovopyranosyl) Glycerol (3): White powder. ${ }^{1} \mathrm{H}-\mathrm{NMR}\left(500 \mathrm{MHz}, \mathrm{CDCl}_{3}+\mathrm{CD}_{3} \mathrm{OD}\right) \delta_{\mathrm{H}}: 4.40(1 \mathrm{H}, \mathrm{dd}$, $J=11.6,3.0 \mathrm{~Hz}, \mathrm{H}-1 \mathrm{a}), 4.11(1 \mathrm{H}, \mathrm{dd}, J=11.6,6.8 \mathrm{~Hz}, \mathrm{H}-1 \mathrm{~b}), 5.26(1 \mathrm{H}, \mathrm{m}$, $\mathrm{H}-2), 3.56$ (1H, dd, $J=11.0,6.0 \mathrm{~Hz}, \mathrm{H}-3 \mathrm{a}), 3.86(1 \mathrm{H}, \mathrm{dd}, J=11.0,5.0 \mathrm{~Hz}, \mathrm{H}-$ 3b), $4.81\left(1 \mathrm{H}, \mathrm{d}, J=3.6 \mathrm{~Hz}, \mathrm{H}-1^{\prime}\right), 3.56(1 \mathrm{H}$, overlapped, H-2'), $3.73(1 \mathrm{H}$, dd, $\left.J=9.0,9.5 \mathrm{~Hz}, \mathrm{H}-3^{\prime}\right), 3.57$ (1H, overlapped, H-4'), 3.98 (1H, ddd, $J=2$, $\left.9.2,9.5 \mathrm{~Hz}, \mathrm{H}-5^{\prime}\right), 3.34$ ( $\left.1 \mathrm{H}, \mathrm{dd}, J=2,14.3 \mathrm{~Hz}, \mathrm{H}-6^{\prime} \mathrm{a}\right), 3.24$ ( $1 \mathrm{H}, \mathrm{dd}, J=9.2$, $\left.14.3 \mathrm{~Hz}, \mathrm{H}-6^{\prime} \mathrm{b}\right), 0.85$ (6H, t, $\left.J=6.4 \mathrm{~Hz}, \mathrm{Me}-16^{\prime \prime}\right), 1.22$ (48H, br s, H-4" to H$\left.15^{\prime \prime}\right), 1.55$ (4H, m, H-3"), $2.29\left(4 \mathrm{H}, \mathrm{m}, \mathrm{H}-2^{\prime \prime}\right) .{ }^{13} \mathrm{C}-\mathrm{NMR}(125 \mathrm{MHz}$, $\left.\mathrm{CDCl}_{3}+\mathrm{CD}_{3} \mathrm{OD}\right) \delta_{\mathrm{C}}: 63.0(\mathrm{t}, \mathrm{C}-1), 70.1(\mathrm{~d}, \mathrm{C}-2), 67.3(\mathrm{t}, \mathrm{C}-3), 98.9\left(\mathrm{~d}, \mathrm{C}-1^{\prime}\right)$, 71.4 (d, C-2') 72.7 (d, C-3'), 73.4 (d, C-4'), 67.8 (d, C-5'), 53.6 (t, C-6' $)$, $174.2\left(\mathrm{~s}, \mathrm{C}-1^{\prime \prime}\right), 34.4\left(\mathrm{t}, \mathrm{C}-2^{\prime \prime}\right), 25.0\left(\mathrm{t}, \mathrm{C}-3^{\prime \prime}\right), 29.2-29.8\left(\mathrm{t}, \mathrm{C}-4^{\prime \prime}-13^{\prime \prime}\right), 31.9$ (t, C-14"), 22.7 (t, C-15"), 14.1 (q, C-16"). IR (KBr) cm ${ }^{-1}:$ 3350, 2922, 1734, 1121, 1028, 1104, 792. Negative ESI-MS m/z: $793[\mathrm{M}-1]^{-} .[\alpha]_{\mathrm{D}}^{25}+42.5^{\circ}$ $(c=1, \mathrm{MeOH})$.

Acknowledgments The authors are grateful to the Knowledge Innovation Project Field Forward Position Program of the South China Sea Institute of Oceanology, The Chinese Academy of Sciences (grant: LYQ200307), Knowledge Innovation Program of the Chinese Academy of Sciences (grant: KZCX3-SW-216), and Guangdong Natural Science Foundation (2003) 11 for financial support. 


\section{References}

1) Zhang J. B., "Marine Medicament and Effection," Traditional Chinese Medical Science Ancient Books Press, Beijing, 1998, pp. 186-187.

2) Tang H. F., Yi Y. H., Yao X. S., Chin. Pharm. J., 37, 262-265 (2002).

3) Xu S. H., Ding L. S., Wang M. K., Chin. J. Org. Chem., 22, 138-140 (2002).

4) Liu H. B., Cui Z., Li Y. S., Chin. Pharm. J., 33, 464-466 (1998).

5) Tang H. F., Yi Y. H., Yao X. S., Chin. Marine Medic., 5, 5-9 (2002).

6) Luca R., Nunziatina D. T., Ingeborg B., Phytochemistry, 45, 647-650 (1997).

7) Tang H. F., Yi Y. H., Yao X. S., Lin H. W., J. Asian Nat. Prod. Res., 4,
95-101 (2002).

8) Tang H. F., Yi Y. H., Yao X. S., "Marine Natural Productions and Natural Biochemistry Medicaments Collected Papers," Beihai, China, 2001, pp. 20-30.

9) Yang H., Jiang B., Hou A. J., Lin Z. W., Sun H. D. J., Asian Nat. Prod. Res., 2, 177-185 (2000).

10) Kong L. Y., Wen Z. D., Shi J. J., Acta Botanica Sinica, 38, 161-166 (1996).

11) Dharma R. K., Trevor G. R., Donald M. S., Biochemistry, 24, 519525 (1985).

12) Jung J. H., Lee H., Kang S. S., Phytochemistry, 42, $447-452$ (1996). 